\title{
Nilai-Nilai Pemberdayaan Konseli Berbasis Feminisme Khas Soekarno: Studi Hermeneutika Gadamerian buku Sarinah
}

\author{
Masbahur Roziqi \\ SMK Negeri 1 Probolinggo \\ e-mail: masbahurroziqi@gmail.com
}

\begin{abstract}
Abstrak: Penelitian ini bertujuan menggali nilai pemberdayaan konseli yang bisa diambil dari karya Soekarno. Soekarno yang memiliki pemikiraan luas untuk kemajuan perempuan Indonesia menuangkan berbagai pemikiran dalam buku berjudul Sarinah. Ruang lingkup penelitian mencakup pemikiran nilai pemberdayaan perempuan yang terdapat dalam buku Sarinah. Ada pun metode penelitian yang digunakan adalah studi hermeneutika Gadamerian. Metode ini menggali nilai pemberdayaan konseli dari teks masa lampau yakni teks tulisan Bung Karno tentang perempuan saat zaman revolusi kemerdekaan lalu. Ada pun dari hasil penelitian didapatkan nlai pemberdayaan konseli khas berbasis feminisme khas Bung Karno antara lain: (1) anti penindasan; (2) adil; (3) menjunjung kesetaraan; (4) berpikir terbuka; (5) koreksi diri; (6) percaya diri; (7) memahami orang lain; (8) bekerjasama. Teks tersebut dapat menjadi bahan masukan idealitas konseli yang dapat difasilitasi oleh konselor.
\end{abstract}

Kata kunci: Sarinah; Pemberdayaan Konseli; Soekarno

\section{PENDAHULUAN}

Konseli adalah subjek utama dalam layanan Bimbingan dan Konseling (BK). Sebagai bagian integral dari pendidikan, bimbingan dan konseling memiliki peran besar untuk melayani konseli. Bukan melayani sebagai objek, melainkan menjadi subjek. Semua kegiatan yang dilakukan konselor, harus bertujuan utama memberi kesejahteraan pada konseli. Tujuan penyejahteraan konseli ini juga tertuang jelas dalam landasan hukum penyelenggaraan bimbingan konseling di sekolah, Permendikbud nomor 111 tahun 2014. Dalam pasal 1 ayat 1 disebutkan

"Bimbingan dan konseling adalah upaya sistematis, objektif, logis, dan berkelanjutan serta terpogram yang dilakukan oleh konselor atau guru bimbingan dan konseling untuk menfasilitasi perkembangan peserta didik/konseli untuk mencapai kemandirian dalam kehidupannya."

Ketika konseli mampu terbantu untuk mencapai kemandirian dalam kehidupannya, maka tujuan utama bimbingan dan konseling telah tercapai. Dengan beragama keunikan budaya yang dibawa konseli, konselor/guru BK memiliki tanggung jawab besar untuk membuat konseli menyadari potensi dirinya untuk mandiri.

Bahkan dalam panduan operasional penyelenggaraan bimbingan dan konseling di sekolah yang diterbitkan Direktorat Jenderal Guru dan Tenaga Kependidikan tahun 2016, kemandirian menjadi aspek penting bagi pengembangan kepribadian konseli. Seperti yang 
termaktub dalam panduan tersebut, ada 11 aspek Standar Kompetensi Kemandirian Peserta Didik (SKKPD) yang berhubungan dengan tugas perkembangan konseli.

Pentingnya pemenuhan aspek SKKPD itu menjadi tulang punggung utama layanan BK yang harus diwujudkan untuk melayani konseli. Paparan panduan operasional memaparkan sebagai berikut:

“Aspek-aspek perkembangan dalam SKKPD selanjutnya menjadi rumusan kompetensi yang dirujuk oleh konselor/guru bimbingan dan konseling dalam mempersiapkan rancangan pelaksanaan dari berbagai layanan bimbingan dan konseling. Rumusan kompetensi tersebut dikembangkan lebih rinci menjadi tugas-tugas perkembangan yang harus dicapai oleh peserta didik/konseli dalam berbagai tataran internalisasi tujuan, yaitu pengenalan, akomodasi, dan tindakan."

Menilik pentingnya tujuan utama memandirian konseli tersebut berarti diperlukan sebuah usaha-usaha konkrit dari konselor. Berbagai upaya bisa dilakukan untuk membuat konseli mencapai aspek kemandirian. Sebab, semakin konseli mampu mandiri, berarti kesejahteraan konseli bisa dikatakan telah terpenuhi.

Dalam studi yang dilakukan oleh Carl Rogers (dalam Boeree, 2013 : 286), Rogers mendasarkan teorinya pada satu daya hidup, yakni kecenderungan aktualisasi. Ini dapat diartikan sebagai motivasi yang menyatu dalam setiap diri makhluk hidup yang bertujuan mengembangkan seluruh potensi-potensinya sebaik mungkin. Rogers yakin bahwa seluruh makhluk pasti ingin berbuat atau memperoleh yang terbaik bagi keberadaannya.

Pentingnya kemandirian untuk dicapai konseli itu juga dikemukakan oleh Erik Eriksson (dalam Boeree, 2013 : 86-88). Erik mengungkapkan tugas yang harus dilakukan oleh tahap kelima atau tahap remaja adalah pencapaian identitas pribadi. Identitas pribadi berarti mengetahui siapa remaja dan bagaimana cara terjun ke tengah masyarakat. Pencarian identitas pribadi akan melibatkan seluruh hal yang remaja ketahui dan pelajari tentang kehidupan dan diri remaja sendiri serta kemudian menggodoknya menjadi satu kesatuan citra diri, sosok yang akan dirujuk oleh masyarakat lingkungan remaja tinggal.

Kesejahteraan konseli menurut Eriksson adalah ketika konseli memperoleh kesetiaan. Yaitu kemampuan hidup berdasarkan standar yang berlaku di tengah masyarakat. Konseli mengetahui dan menemukan posisinya di dalam masyarakat, tempat yang memungkinkan konseli berperan sesuai dengan kemampuan yang konseli miliki. Konseli mandiri mendapatkan posisinya di tengah masyarakat.

Tak hanya oleh Eriksson, mantan presiden Chili yang dikudeta oleh angkatan bersenjata Chile pada 11 September 1973, Salvador Allende (1973), menekankan pentingnya kemandirian bagi masyarakat. Pemberdayaan masyarakat tersebut dipekikkan Allende lewat cuplikan pidato terakhirnya pada rakyat Chili.

"The people must defend themselves, but they must not sacrifice themselves. The people must not let themselves be destroyed or riddled with bullets, but they cannot be 
humiliated either. I have faith in Chile and its destiny. Other men will overcome this dark and bitter moment when treason seeks to prevail. Go forward knowing that, sooner rather than later, the great avenues will open again where free men will walk to build better society"

Allende menegaskan walau dalam situasi paling krusial apa pun, kesejahteraan masyarakat berupa kemandirian tetap lah harga mati. Terbukti menjelang kematiannya di tangan militer, Allende yakin dan percaya suatu saat akan ada seseorang yang mampu membebaskan masyarakat untuk mandiri membangun masyarakat yang lebih baik.

Kesejahteraan berupa kemandirian konseli ini pula yang dikemukakan Albert Ellis, meskipun dalam bentuk yang berbeda. Ellis (dalam Boeree, 2013 : 177) mengatakan bahwa konseli memiliki kemampuan dan bisa meraih kesuksesan-ksuksesan hidup serta berupaya meruntuhkan keyakinan akan ketidakmampuan yang ada di dalam dirinya. Menurut Ellis, konseli perlu mandiri untuk tidak terjebak dalam pikiran-pikiran irasional, dan mengedepankan pikiran rasional.

Beberapa pendapat para ilmuwan barat tersebut, memang didapat dalam interaksi mereka dengan masyarakat barat. Penafsiran atas kesejahteraan konseli berupa kemandirian berasal atas pengkajian mereka atas kehidupan barat yang banyak didominasi asas dan terkungkung sistem kapitalisme. Bimbingan dan konseling yang ditelurkan para ilmuwan tersebut, praktis adalah bimbingan dan konseling yang secara tidak langsung dibumbui kapitalisme. Sebuah paham yang mengagungkan kebebasan individu dan mekanisme pasar.

Alhasil pemberdayaan konseli pun diwarnai oleh esensi kapitalisme. Dalam masyarakat kapitalisme asal para ilmuwan pencetus BK tersebut terdapat prinsip individualistik yang menjadi cirinya. Alexis de Tocqueville (dalam Lekachman dan Van Loon, 2008 : 10) menyatakan bahwa tidak ada negara lain mana pun di dunia dimana kecintaan terhadap kepemilikan barang-barang lebih besar atau lebih bersemangat ketimbang di Amerika Serikat. Dan tidak ada di tempat lain mana pun dimana mayoritas penduduknya cenderung enggan pada doktrin-doktrin yang dapat mengancam hak kepemilikan. Para ilmuwan barat setidaknya membawa prinsip kapitalisme tersebut dalam pemikiran mereka. Mereka berlomba sebisa mungkin menyebarkan ilmu pemahaman kepribadian manusia lewat prinsip kapitalisme. Terutama bagaimana kemandirian ala negara kapitalis bisa diadaptasi di dunia ketiga seperti Amerika Latin, Afrika, hingga Asia.

Berkaca dari hal tersebut, tak dapat dipungkiri, Indonesia telah sejak lama masuk dalam pertarungan ideologi keilmuan BK. "Perang dingin" menentukan konsep pemberdayaan konseli berupa kemandirian telah dilumuri konsep-konsep kapitalisme sejak awal masuknya. Termasuk pula ide-ide kemandirian konseli dalam feminisme. Sebuah ide pemberdayaan konseli untuk bangkit dari himpitan ketidakberdayaan yang didominasi perempuan. 
Menurut Marisa Rueda dkk (2007 : 3) feminisme ialah tentang perlawanan terhadap pembagian kerja di suatu dunia yang menetapkan kaum laki-laki sebagai yang berkuasa dalam ranah publik. Sementara kaum perempuan hanya menjadi pekerja tanpa upah di rumah, dan memikul seluruh beban kehidupan keluarga. Pemahaman feminisme Marisa Rueda dkk ingin menegaskan pentingnya kemandirian konseli perempuan untuk melawan segenap struktur kekuasaan, hukum, dan aturan yang menjadikan perempuan sebagai rendah, subordinat dan kelas dua.

Di tengah gencarnya arus pemikiran kapitalisme dalam pemberdayaan konseli, feminisme menjadi daya tarik untuk menjadi salah satu tawaran pemberdayaan. Namun tentu bukan konsep feminisme kapitalis yang dibawa dunia barat. Nilai-nilai pemberdayaan konseli tersebut harus lah sesuai dengan karakteristik bangsa Indonesia. Diambil dari pemikiran yang hidup dan berkembang dalam masyarakat Indonesia. Salah satunya adalah konsep feminisme yang dicetuskan anak bangsa, Ir.Soekarno, presiden pertama Republik Indonesia.

Soekarno atau akrab dipanggil Bung Karno membedah pentingnya peran perempuan dalam konsep feminisme Indonesia. Sambil menyerap banyak pandangan dunia barat, Soekarno menggagas sendiri konsep-konsep pemberdayaan perempuan. Semua dia tuangkan dalam buku Sarinah : Kewajiban Wanita dalam Perjuangan Republik Indonesia.

Perempuan memiliki banyak hal untuk dikaji. Demikian Soekarno menyimpulkan dalam pengantar pendahuluan buku Sarinah. Pernyataan lengkapnya sebagai berikut :

"Sayang sekali bahwa soal wanita itu belum pernah dipelajari sungguh-sungguh oleh pergerakan kita. Sebab kita tidak dapat menyusun negara dan tidak dapat menyusun masyarakat, jika kita tidak mengerti soal wanita. Itu lah sebabnya saya, mengadakan kursus-kursus wanita itu" (Soekarno, 2014:viii)

Buku Sarinah yang lahir dari kursus pemberdayaan perempuan yang diselenggarakan Bung Karno, menjadi bekal pemberdayaan yang berasal dari kepribadian bangsa Indonesia sendiri. Tanpa dominasi nilai-nilai kapitalisme. Nilai tersebut tidak berangkat dari konsep hak kepemilikan yang dikuasai segelintir pemilik modal, namun justru berangkat dari seorang mbok, atau pekerja rumah tangga. Seperti yang diutarakan Soekarno :

“ Apa sebab saya namakan kitab ini Sarinah? Saya namakan kitab ini Sarinah sebagai tanda terima kasih saya kepada pengasuh saya ketika saya masih kanak-kanak. Pengasuh saya itu bernama Sarinah. Ia "Mbok" saya. Ia membantu ibu saya, dan dari dia saya menerima banyak rasa cinta dan rasa kasih. Dari dia saya banyak mendapat pelajaran mencintai "orang kecil". Dia sendiri pun "orang kecil". Tetapi budinya selalu besar! (Soekarno, 2014 : viii)

Buku Sarinah menjelaskan pemikiran Soekarno tentang perlunya membahas feminisme dari nilai bangsa sendiri. Soekarno menjadikan feminisme sebagai bagian untuk pendidikan bagi masyarakat. Bahwa untuk menjadi bangsa yang merdeka, perlu memiliki pengetahuan luas dan 
berdiri di atas kaki sendiri. Jadi walau pun luas ilmu, namun kepribadian tetap harus berasal dari bangsa sendiri.

Bung Karno mengupas tuntas persoalan feminisme barat dan pemikirannya. Kemudian meramunya dalam wujud buku Sarinah. Tentu saja sebagai bagian dari pemimpin yang mengagumi sosialisme, berprinsip Pancasila, serta anti penghisapan sesama manusia, nilai pemberdayaan kapitalis tidak cocok bagi pemberdayaan bangsa Indonesia. Oleh karenanya, Soekarno menawarkan konsep feminisme berdikari lepas dari nilai-nilai kapitalisme, imperialisme, dan neokolonialisme.

Bimbingan dan konseling Indonesia perlu mempertajam khasanah keilmuannya dalam tawaran feminisme ala Soekarno ini. Prinsip feminisme yang anti penghisapan sesama manusia ini dapat menjadi khasanah keilmuan yang digali dari spirit bangsa Indonesia yang merdeka dan berdaulat.

Tawaran konsep berdikari Soekarno dalam buku Sarinah itu lah yang menarik untuk dikaji. Nilai-nilai pemberdayaan seperti apa yang lantas dapat dijadikan patokan bagi konselor untuk mencapai kesejahteraan konseli berbasiskan feminisme khas Bung Karno.

\section{METODE}

Metode yang digunakan dalam penelitian ini adalah penelitian kualitatif dengan pendekatan hermeneutika Gadamerian. Hermeneutika Gadamerian adalah pendekatan penelitian yang digunakan untuk menafsirkan teks dengan cara berdialog imajiner berdasarkan tahap tertentu. Dalam pendekatan penelitian ini mengutamakan proses dialog antara teks dan penafsir. Pemahaman pada teks didapatkan dari dialog tersebut.

Rahardjo (2008 : 118) mengatakan pokok pemikiran hermeneutik Gadamerian yaitu terdapat sebuah pola lingkaran hermeneutik. Lingkaran tersebut terdiri atas pola naik turun antara bagian (part) dan keseluruhan (whole) untuk memahami makna dalam sebuah teks. Hal ini berarti bagian (part) akan mengubah pemahaman kita pada keseluruhan dan sebaliknya pengubahan pada pemahaman kita terhadap keseluruhan (whole) akan mengubah pemahaman kita pada bagian dan seterusnya.

Sumber data penelitian ini terbagi menjadi dua. Yakni sumber buku primer yakni teksteks yang terdapat dalam buku Sarinah karya Soekarno. Sedangkan sumber sekunder adalah buku-buku pendamping yang mendukung penguatan kajian penelitian ini. Teks-teks buku Sarinah mendominasi penelaahan nilai pembedayaan konseli berbasis feminisme khas Bung Karno.

Ada pun prosedur pengumpulan data yang digunakan dalam penelitian ini antara lain : Pertama, mencari sumber primer penelitian yakni buku teks Sarinah karya Soekarno. Kedua, mengumpulkan sumber sekunder, yaitu buku yang berkaitan dengan penguatan kajian buku 
Sarinah. Ketiga, proses reduksi data. Prosedur terakhir ini berarti menetapkan dan mengumpulkan sumber-sumber yang sesuai dengan tujuan penelitian, serta menyisihkan data yang tidak berkaitan dengan penelitian.

Instrumen penelitian adalah peneliti sendiri. Peneliti memegang peran utama dalam pelaksanaan penelitian ini. Penafsiran dan penganalisisan data dilakukan peneliti. Ini seperti yang diungkapkan Patterson dan Williams (2002 :42) from an hermeneutic perspective, the researcher must adopt the role of "self as instrumen". Konsep peneliti sebagai instrumen ini digunakan dengan alasan bahwa upaya menggali dan memaknai nilai pemberdayaan konseli berbasis feminisme khas Bung Karno.

Analisis data yang digunakan dalam penelitian ini menggunakan teknik part-whole. Data yang digunakan berupa hasil pemaknaan dan interpretasi dari pengkajian buku teks Sarinah karya Soekarno. Menurut Alvesson dan Skoldberg (2000 : 53) dalam perspektif hermeneutik Gadamerian, analisis data buku teks disebut lingkaran hermeneutik (hermeneutic circle). Yakni peneliti dihadapkan pada analisis bagian (part) dan keseluruhan (whole).

Mappiare (2013 : 123) juga menjelaskan langkah-langkah dalam melakukan analisis hermeneutika Gadamerian meliputi : Pertama, penafsiran bagian-bagian, unsur atau bagian. Kedua, penafsiran keseluruhan, keutuhan (whole), dan Ketiga, mendapatkan pemahaman pada yang melandasi makna (understanding of underlying meaning).

Selain itu dalam penelitian hermeneutika Gadamerian perlu dijabarkan tahap-tahap penelitian. Tahap penelitian ini terdiri atas : Pertama, menetapkan buku sumber primer penelitian yakni buku Sarinah karya Soekarno. Kedua, praandaian. Yakni upaya untuk menafsirkan atau menggambarkan makna apa yang ingin diperoleh dalam penelitian teks yang dikaji. Ada pun langkah yang dilakukan dalam tahap praandaian ini antara lain : a) membaca berulang-ulang ; b) menentukan fokus penelitian yang dapat diserap sebagai nilai pemberdayaan konseli berbasis feminisme khas Soekarno ; c) membaca buku sumber yang relevan dengan fokus penelitian. Ketiga, realitas historis. Tahap ini terdiri dari beberapa langkah antara lain : a) pembentukan data, dilakukan dengan membaca dan mengkaji buku yang sesuai dengan tulisan asli dalam teks maupun dengan memberikan kesimpulan tersendiri ; b) Pereduksian data, tujuannya agar data yang tidak memiliki relevansi dengan penelitian bisa dieliminasi. Sehingga data yang dipadukan adalah data yang telah terfilter dan relevan yaitu nilai pemberdayaan konseli ; c) Penarikan inferensi, adalah tafsiran makna kata atau pesan yang terdapat dalam teks buku Sarinah karya Soekarno. Tafsiran tersebut didasarkan pada konteks budaya dan historis berlandaskan konsepsi Soekarno. Ketiga, hasil kajian (produksi). Tahap ini berupa memperoleh gambaran atau deskripsi tentang nilai pemberdayaan konseli berbasis feminisme khas Soekarno yang terdapat dalam buku Sarinah. 


\section{HASIL}

Hasil dalam penelitian ini berupa paparan data dan penafsiran. Paparan data dan penafsiran adalah serangkaian bagian dari sebuah karya ilmiah yang berisi pemaparan atas datadata yang telah diperoleh, penemuan dari hasil olah pikir peneliti atas obyek penelitan yang dikaji. Pengkajian dari penelitian ini difokuskan atas buku Sarinah sebagai sumber utama kajian penelitian ini.

Penafsiran atas nilai pemberdayaan konseli juga dipaparkan dalam bab ini. Penafisiran dilakukan dengan pembacaan buku secara cermat dan mendalam. Segala tafsiran pemikiran tentang nilai pemberdayaan konseli dari Bung Karno yang dituangkan dalam buku tersebut dicari dan selanjutnya dipaparkan sebagai berikut.

\section{Deskripsi dan Penafsiran Nilai Anti Penindasan}

Deskripsi dan penafsiran dari nilai anti penindasan yang disampaikan Bung Karno, dipaparkan sebagai berikut :

"Revolusi patriarchat ini bukan revolusi yang memerdekakan kaum laki-laki dengan memelihara kemerdekaan perempuan, tetapi menjadilah satu revolusi yang memerdekakan kaum laki-laki dengan mengorbankan kemerdekaan perempuan! Perlawanan kaum perempuan terhadap revolusi ini tentu menjadi sebab pula bagi kaum laki-laki itu untuk melipat kaum perempuan itu sama sekali, merampas kemerdekaan yang ada para perempuan itu sama sekali, merampas segala kemerdekaan yang ada pada perempuan itu sama sekali. Perlawanan kaum perempuan itu sebagai di dalam tiap-tiap revolusi, menjadilah sebabnya kaum yang membuat revolusi itu mengadakan diktator : Diktator kaum laki-laki untuk mematahkan kontra revolusinya kaum perempuan" (Soekarno, 2014: 67)

Nilai pemberdayaan antipenindasan tampak pada penafsiran tersebut. Bung Karno menjelaskan perempuan mengalami penindasan sejak terjadi revolusi patriarki yang dilakukan laki-laki. Sehingga kemerdekaan sebagai manusia banyak terenggut oleh dominasi patriarki laki-laki. Nilai pemberdayaan antipenindasan ini dapat diadopsi untuk konseli. Kemerdekaan sebagai bagian hak asasi manusia paling dasar perlu dimiliki konseli. Tujuannya, agar konseli dapat mandiri dan maksimal dalam pengembangan potensinya. Ketika mampu mandiri dan tidak tertindas, peluang untuk memaksimalkan potensi terbuka lebar.

Feminisme menurut Bung Karno adalah lepas dari penindasan. Sebab hakikat manusia adalah merdeka untuk mengatur diri sendiri. Mandiri menjalani hidupnya. Demikian dengan konseli. Konseli yang merdeka jauh lebih berdaya dibandingkan konseli yang mengalami penindasan.

\section{Deskripsi dan Penafsiran Nilai Adil}

Deskripsi dan penafsiran nilai Adil yang disampaikan Bung Karno dipaparkan sebagai berikut :

"Tak sehatlah masyarakat itu, manakala, salah satu pihak menindas kepada yang lain, tak peduli pihak yang mana yang menindas dan tak peduli pihak mana yang tertindas. Masyarakat itu 
hanyalah sehat, manakala ada perimbangan hak dan perimbangan perlakuan antara kaum lakilaki dan perempuan, yang sama tengahnya, sama beratnya, sama adilnya" (Soekarno, 2014: 39)

Pada paparan tersebut, tampak Bung Karno tak ingin membela laki-laki maupun perempuan. Dengan tegas dia menegaskan salah satu tidak boleh menjadi penindas bagi yang lain. Jika ada hal seperti itu, maka masyarakat tersebut tidak sehat. Keadilan itu terjadi menurut Bung Karno karena terjadi perimbangan antara laki-laki dan perempuan. Tidak saling menindas satu sama lain. Keduanya memiliki hak yang melekat pada diri masing-masing. Perlakuan antara kedua nya pun harus lah saling adil. Sebab keadilan mendatangkan masyarakat yang sehat.

Demikian dengan konseli. Nilai pemberdayaan pada konseli perlu dilandasi nilai adil ini. Ketika konseli mampu berdaya dengan berlandaskan keadilan dalam kehidupannya, maka ketenangan pikiran dan hati akan muncul. Konseli akan berpikir ribuan kali untuk memperlakukan orang lain dengan tidak adil.

\section{Deskripsi dan Penafsiran Nilai Menjunjung Kesetaraan}

Deskripsi dan penafsiran nilai menjunjung kesetaraan yang disampaikan Bung Karno dipaparkan sebagai berikut :

"Satu sistem yang memperbudakkan perempuan tidaklah sehat, satu sistem yang memperbudakkan laki-laki pun tidaklah sehat. Yang sehat hanyalah satu sistem, di mana lakilaki dan perempuan sama-sama merdeka, sama-sama beruntung, sama-sama bahagia" (Soekarno, 2014: 99)

Dalam paparan tersebut, Bung Karno dengan tegas mengatakan antara laki-laki dan perempuan itu harus lah setara. Tak boleh ada yang memperbudak satu dengan yang lain. Samasama merdeka, sama bahagia, itu lah nilai yang perlu ada pada tiap orang, baik laki-laki maupun perempuan. Sebuah sistem yang manusia di dalamnya menjunjung tinggi kesetaraan merupakan sistem yang sehat. Demikian pula dengan konseli. Konseli akan lebih berdaya ketika mereka menjunjung kesetaraan. Tidak membedakan antar manusia. Saling menghargai tanpa perlu merendahkan, apalagi memperbudak.

Bung Karno mewariskan feminisme berupa penjunjungan tinggi kesetaraan antar manusia. Sebab selama ini bangsa Indonesia telah lama hidup dalam ketidaksetaraan di bawah rezim kolonial asing. Kemandirian konseli sebagai generasi penerus harus berlandaskan semangat menjunjung kesetaraan.

\section{Deskripsi dan Penafsiran Nilai Berpikir Terbuka}

Deskripsi dan penafsiran nilai berpikir terbuka yang disampaikan Bung Karno dipaparkan sebagai berikut :

"Bahwasanya, memang di kalangan si Marhaen inilah, karena dorongan "struggle for life", kaum perempuan lebih merdeka, lebih tidak terikat di rumah daripada kalangannya kaum-kaum 
yang agak mampu, yang kadang-kadang mengurung perempuannya itu mengasih alasan, bahwa mereka menutup istri-istrinya dan putri-putrinya itu ialah untuk memelihara mereka, untuk mengenakkan hidup mereka, untuk memuliakan kedudukan mereka. Ya.... "memuliakan" mereka.... Tetapi "memuliakan" mereka dengan memperlakukan mereka sebagai blasteran dewi dan si tolol!"” (Soekarno, 2014 :35-36)

Gagasan berikutnya berdasarkan feminisme khas Bung Karno adalah berpikir terbuka. Dalam pemaparan penafsiran nilai berpikir terbuka, dia menolak dalih melindungi perempuan dengan mengurung mereka. Sebab menurutnya konsep melindungi itu justru malah membodohkan perempuan. Perempuan tidak akan tahu apa-apa ketika mereka diterungku, tidak boleh menikmati kemerdekaan mereka.

Pemikiran Bung Karno itu menjelaskan pentingnya nilai berpikir terbuka. Dengan berpikir terbuka, maka para lelaki tidak menjadikan perempuan sebagai bawahan atau budak, melainkan partner. Ketika peran perempuan sudah mulai terbuka untuk berkarya di luar rumah, para lelaki diharapkan tidak malah menghalangi perempuan memenuhi perannya. Bekerja bahu membahu mengisi kehidupan bersama. Pemikiran terbuka ini lah yang melandasi Bung Karno menelurkan gagasan feminisme tersebut. Nilai pemberdayaan berpikir terbuka ini perlu dimiliki idealnya oleh konseli. Proses kemandirian yang dilalui konseli perlu berlaskan pemikiran terbuka. Ketika konseli mampu membuka pemikirannya untuk menerima hal baru, maka wawasannya menjadi lebih luas.

\section{Deskripsi dan Penafsiran Nilai Koreksi Diri}

Deskripsi dan penafsiran percaya diri yang disampaikan Bung Karno dipaparkan sebagai berikut :

"Hukum perbapaan yang menindas dan merampok, memperlakukan perempuan sebagai benda dan sebagai ternak, hukum perbapaan yang liar itu dikoreksi hendak diganti dengan hukum perbapaan yang lebih baik dan adil" (Soekarno, 2014: 124)

Bung Karno menegaskan sikap koreksi diri sangat diperlukan untuk merevisi tindakan tidak baik pada orang lain. Seperti yang disampaikan Bung Karno ketika menentang sistem patriarki (mengutamakan lelaki) tidak baik yang dipraktikkan beberapa manusia pada manusia lain. Dalam hal ini laki-laki terhadap perempuan. Dia mengatakan koreksi diri perlu dilakukan agar tindakan yang dilakukan jauh lebih baik dan adil. Ketika mampu saling mengoreksi diri, maka kesalahan yang diperbuat tidak akan terulang pada kemudian hari. Dengan tegas Bung Karno menganggap peraturan yang mengekang perempuan bukan lah hal yang perlu dipertahankan. Perlu dikoreksi menjadi lebih baik.

Nilai pemberdayaan koreksi diri ini perlu ada pada konseli. Kemandirian konseli perlu diandasi nilai koreksi diri. Saat mampu mandiri, pasti akan mengalami berbagai tantangan. Salah satunya berbagai kesalahan yang menanti di depan mata. Konseli wajib mengoreksi diri 
atas setiap tindakan yang dilkukan. Ini lah menurut Bung Karno bentuk kedewasaan seseorang. Mau mengoreksi diri dan merevisinya menjadi lebih baik.

\section{Deskripsi dan Penafsiran Nilai Percaya Diri}

Deskripsi dan penafsiran percaya diri yang disampaikan Bung Karno dipaparkan sebagai berikut :

"Saya sendiri waktu menjadi murid di H.B.S mengalami bahwa sering kali murid lelaki "payah" berlomba kepandaian dengan teman-teman perempuan dan malahan pula sering-sering "terpukul" oleh teman-teman perempuan itu. Pada waktu saya menjadi guru di sekolah menengah pun saya mendapat pengalaman, bahwa murid-murid saya yang perempuan umumnya tak kalah dengan murid-murid saya yang laki-laki” (Soekarno, 2014: 25)

Percaya diri menjadi salah satu konsep feminisme yang ditawarkan Bung Karno dalam paparan tersebut. Dia mengungkapkan pengalamannya sendiri saat menjadi murid dan guru. Bahwa tidak selamanya murid perempuan kalah dengan murid laki-laki. Apalagi dalam hal kepandaian. Dengan fakta tersebut, Bung Karno memotivasi para perempuan agar percaya diri. Mereka punya kemampuan. Kemandirian konseli juga harus dilandasi nilai percaya diri. Konseli mampu memberdayakan dirinya dengan modal kepercayaan diri. Percaya pada kemampuan, percaya pada tekad hatinya untuk memandirikan diri.

\section{Deskripsi dan Penafsiran Nilai Memahami Orang Lain}

Deskripsi dan penafsiran mampu memahami orang lain yang disampaikan Bung Karno dipaparkan sebagai berikut :

“ Gerakkanlah massa itu! Itu adalah semboyan yang benar. Tetapi dapatkan orang menggerakkan massa jika tidak mengetahui kehendak-kehendak massa, dan dapatkah orang mengetahui kehendak massa jika tidak bergaul dengan mereka!" (Soekarno, 2014: 312)

Bung Karno menegaskan pentingnya memahami orang lain. Menurutnya, massa rakyat yang terdiri dari beragam kumpulan orang lain baru dapat digerakkan jika sang penggerak mampu mengetahui dan memahami massa tersebut. Caranya, para penggerak itu perlu turun langsung dan berbaur dengan massa. Baru lah kehendak dari massa tersebut akan dapat diketahui. Apa yang mereka inginkan, rasakan, dan hendak dituju. Karakter tiap orang dalam massa tersebut yang menjadi penentu gerakan massa. Ketika penggerak massa mampu memahami karakter tersebut, suara massa rakyat berada dalam genggamannya. Demikian pula dengan konseli. Nilai pemberdayaan memahami orang lain yang dimiliki konseli akan mampu membuatnya menjadi manusia yang tenang menghadapi orang lain. Karena dirinya mampu memahami orang lain tersebut.

\section{Deskripsi dan Penafsiran Nilai Bekerjasama}

Deskripsi dan penafsiran nilai bekerjasama bekerjasama yang dipaparkan Bung Karno sebagai berikut : 
"Adakanlah penggabungan tenaga antara perempuan dan laki-laki yang sehebat-hebatnya, adakanlah perjuangan nasional yang sebulat-bulatnya. Laki-laki dan perempuan bersama ke satu tujuan, tiada satu tenaga pun yang boleh tercecer. Feminis atau sosialis jikalau golongangolongan itu ada, jangan lah menentang satu sama lain, tetapi berjuanglah bahu membahu serapat-rapatnya membela kemerdekaan nasional" (Soekarno, 2014: 327)

Bung Karno menegaskan pentingnya bekerjasama antara laki-laki dan perempuan. Tidak boleh saling menentang antara satu dengan yang lainnya. Meraih tujuah bersama untuk membela kemerdekaan. Konseli diharapkan pula memiliki nilai pemberdayaan bekerjasama ini. Dalam kemandirian bukan diharamkan saling kerjasama. Namun boleh bekerjasama di atas dasar kesetaraan. Bukan kerjasama saling merendahkan.

\section{PEMBAHASAN}

Hasil pengkajian teks-teks dalam buku Sarinah karya Bung Karno menemukan beberapa nilai pemberdayaan berbasis feminisme Bung Karno yang dapat diambil untuk memberdayakan konseli. Nilai-nilai ini Soekarno ambil dari berbagai pengalaman dan pengetahuan yang dia dapatkan. Ada yang berasal dari pengalaman dia sendiri maupun hasil pergulatannya dengan pemikiran para ahli dunia. Semuanya didiskusikan Soekarno dengan realitas yang dia dapati di lingkungan bangsanya.

Diskusi dalam pembahasan ini bertujuan menemukan benang merah antara temuan penelitian dengan beragam teori atau penemuan lain yang telah dulu dipublikasikan. Penarikan benang merah ini tidak berarti temuan peneliti harus sama persis dengan pemikiran atau teori yang dibangun oleh peneliti pendahulu. Namun berprinsip saling mengisi konsep-konsep yang diperlukan untuk pemberdayaan konseli.

Total ada enam nilai pemberdayaan konseli berbasis feminisme khas Bung Karno yang telah didapatkan dari buku Sarinah karya Bung Karno. Pembahasan diskusi mengenai enam nilai tersebut disajikan sebagai berikut :

\section{Nilai pemberdayaan anti penindasan}

Nilai anti penindasan adalah sebuah nilai yang menentang penghisapan manusia atas manusia pada khususnya dan bangsa pada bangsa pada umumnya. Nilai yang disampaikan Bung Karno pada buku Sarinah ini menjadi tonggak konsep memanusiakan manusia sesuai tujuan pendidikan. Pentingnya konseli memiliki nilai anti penindasan ini juga diamini oleh Worell and Remmer (dalam Corey, 2009). Dia mengungkapkan konselor memiliki peran konseli untuk memahami penindasan yang melingkupinya. "Understand how sexist and oppressive societal beliefs and practices influence them in negative ways". Konseli menurut Remmer perlu dibimbing konselor untuk memahami betapa penindasan yang mengendap dalam kepercayaan konseli hanya akan membawa dampak negatif. Ketika konseli paham, maka diharapkan semangat nilai anti penindasan tersebut dapat merasuk ke jiwa sanubari konseli. 
Bung Karno secara konsisten bersikap anti penindasan, dan pentingnya seseorang memiliki nilai tersebut. Remmer mempertegas kekonsistenan nilai anti penindasan yang digaungkan oleh proklamator kemerdekaan Indonesia ini. Ada pun menurut Corey (2009: 350) menjelaskan perlunya konselor menfasilitasi konseli untuk memaksimalkan potensinya. Tidak hanya dari hambatan dalam diri namun dari penindasan atau kekangan sistem. Seperti yang dia utarakan, "Feminist therapists work to free women (and men) from roles that have constrained them from realizing their potential."

Corey mengungkapkan pentingnya konselor bekerja untuk membebaskan konseli (baik perempuan maupun laki-laki) dari sistem yang menindas mereka dari penyadaran atas potensi mereka (konseli). Pandangan Corey ini sejalan dengan cita-cita besar Bung Karno agar setiap orang dalam suatu bangsa tidak lagi mengalami penindasan baik dari sesamanya atau dari bangsa lain. Lebih khusus Bung Karno menegaskan penindasan yang dilakukan laki-laki pada perempuan bukan lah hal yang benar. Sistem patriarki jahat yang menindas perempuan bukan lah bagian dari solusi melainkan menjadi masalah tersendiri. Demikian juga dengan konseli. Bersama dengan konselor, nilai anti penindasan ini perlu menjadi landasan utama pemberdayaan konseli. Berprinsip menjadi berdaya tanpa harus menindas orang lain.

\section{Nilai Pemberdayaan Adil}

Nilai adil menjadi hal yang penting pula dapat dimiliki seorang konseli. Adil berarti menempatkan sesuatu pada tempatnya. Tidak berat sebelah dalam memandang suatu persolan. Menyeimbangkan antara satu hal dengan hal lain dengan melihat berbagai perspektif.

Nilai pemberdayaan adil Bung Karno ini juga senada dengan temuan penelitian terdahulu dalam sumber lain. Anisah Prafitralia (2015: abstrak) menyimpulkan salah satu nilai pribadi ideal konseli adalah berkeadilan sosial, yakni bertindak adil dan tidak mengambil hak milik orang lain. Ketika konseli mampu adil, maka dia tidak akan semena-mena para orang lain. Salah satunya tidak merampas apa yang menjadi milik orang lain. Gagasan besar Bung Karno tentang nilai pemberdayaan adil dapat diserap menjadi nilai pemberdayaan konseli. Dengan menerapkan nilai adil, konseli menempatkan diri sebagai pihak yang bijak terutama dalam mengambil keputusan.

\section{Nilai Pemberdayaan Menjunjung Kesetaraan}

Kesetaraan adalah nilai pemberdayaan konseli perlu menjadi bagian dari hal yang ada pada konseli untuk menggapai kemandirian. Bung Karno mencetuskan dalam buku Sarinah ini perlunya laki-laki dan perempuan menjunjung kesetaraan. Artinya tiap pihak berada pada kedudukan yang sama. Memiliki hak dan kewajiban masing-masing sesuai perannya. Tidak saling menjatuhkan. 
Bung Karno yang mengetahui sedikitnya peran perempuan dalam peran masyarakat, menggugat hal tersebut. Dia menegaskan pentingnya kesetaraan itu dimiliki baik laki-laki maupun perempuan. Demikian pula yang disampaikan Corey (dalam Muwakhidah, 2017) bawah konseli diharapkan menjadi pribadi sehat agar semakin berdaya. Pribadi sehat menurut terapi feminis adalah individu yang mampu memiliki kesetaraaan gender dan memiliki kekuasaan/kontrol terhadap dirinya sendiri.

Corey menegaskan bahwa pribadi sehat mampu berdiri sejajar dan setara dengan orang lain. Pribadi tersebut mampu menciptakan iklim penuh kebermaknaan dan saling respek. Sekaligus memiliki kekuasaan/kontrol diri untuk menciptakan suasana kesetaraan itu. Pendapat senada diungkapkan oleh Lazarus (dalam Windy Draden and Jill Myton, 1999: 142) yang menjelaskan bahwa :

"Lazarus believes that we are all equal to one another no one is superior, not the queen, nor the prime minister, nor religious leaders, not even Mother Theresa. He calls this the principle of parity. The fact that some people have superior skills in certain areas does not make them superior human beings. He believes we should respect people's abilities without making them gods. He agrees with Ellis that we are all fallible yet acceptable people we all have limitations as well as assets."

Dalam kutipan tersebut, Lazarus percaya bahwa tiap orang memiliki kedudukan setara antara satu dengan yang lainnya. Tidak ada yang lebih superior, entah itu ratu, perdana menteri bahkan pemimpin agama, termasuk bunda Theresa. Lazarus mengungkapkan fakta bahwa tidak berarti orang yang memiliki kemampuan superior menjadikannya lebih superior dari manusia lain. Dia percaya bahwa setiap orang harus menghargai kemampuan orang lain tanpa menjadikannya Dewa. Lazarus setuju dengan Ellis bahwa tiap orang punya keterbatasan. Pemikiran Lazarus ini semakin menguatkan temuan nilai menjunjung kesetaraan Bung Karno. Pemberdayaan konseli perlu memperhatikan nilai menjunjung kesetaraan. Untuk berdaya, konseli tidak perlu harus membuat orang lain menjadi lebih rendah daripadanya. Namun berprinsip untuk saling setara dan tidak menjatuhkan. Menghargai orang lain setara dengan dia menghargai diri sendiri. Tidak melebihkan atau merendahkan.

\section{Nilai Pemberdayaan Berpikir Terbuka}

Berpikir terbuka termasuk bagian dari nilai pemberdayaan yang perlu melandasi kemandirian konseli. Bung Karno menegaskan perlunya para perempuan dan laki-laki berpikir terbuka, memiliki sudut pandang luas, tidak hanya melihat pada dirinya saja. Sehingga meminimalisir pemikiran bias yang kemungkinan muncul setiap menghadapi realitas.

Pusat Studi Authentic Happiness Universitas Pennsylvania (2017) menyumbang pemikiran senada dengan Bung Karno terkait pentingnya nilai pemberdayaan berpikir terbuka bagi individu, khususnya konseli. Mereka menjabarkannya, Open-mindedness is the willingness 
to search actively for evidence against one's favored beliefs, plans, or goals, and to weigh such evidence fairly when it is available.

Berpikir terbuka keinginan untuk mencari dengan aktif bukti yang dapat melawan satu sisi kepercayaan, rencana atau tujuan, dan menimbang bukti tersebut dengan fair ketika bukti itu ada. Artinya individu diharapkan tidak terpancang pada satu pemikiran saja. Dia perlu untuk mencari pemikiran lain yang dapat memperkaya wawasannya. Sehingga pemikirannya tidak terkungkung pada satu sisi pemikiran saja.

\section{Nilai Pemberdayaan Koreksi Diri}

Nilai pemberdayaan koreksi diri mencerminkan pemikiran kuat Bung Karno atas penentangan sikap sombong. Dan keteguhannya untuk merevisi pemikiran atau tindakan yang keliru. Mengaku keliru dan membenarkan kesalahan yang telah diperbuat jauh lebih baik daripada berpura-pura tidak tahu dan mendiamkan kesalahan tersebut. Bung Karno dalam buku Sarinah, mengajak para laki-laki dalam sistem patriarki jahat untuk mengubah itu semua. Tanpa merendahkan laki-laki, dia mengajak mereka untuk dengan ksatria memberdayakan perempuan, yang artinya mengoreksi kesalahan lelaki yang selama ini menindas perempuan.

Ada pun nilai pemberdayaan koreksi diri ini diamini oleh pakar pendekatan eksistensialisme, Nietzsche. Menurut Nietzsche (2017: 238), menghasrati kebenaran dan berusaha menjauhi kesalahan sejatinya adalah sikap memusuhi kehidupan. Konseli menurutnya perlu merangkul keduanya. Baik kebenaran dan kesalahan. Sebab jika konseli atau individu hanya menerima kebenaran dan menolak segala sesuatu yang tidak sesuai dengan kebenarannya sendiri berarti dia mengamputasi kehidupan. Pemikiran Nietzsche menguatkan pandangan Bung Karno bahwa kesalahan individu tidak lah perlu dijadikan kesalahan selamanya. Namun yang paling penting adalah individu itu mau dan mampu mengoreksi dirinya.

Demikian pula dengan konseli. Ketika nilai pemberdayaan koreksi diri mampu muncul dan diterapkan konseli, maka konseli akan mampu mengetahui kesalahan-kesalahannya dna belajar dari kesalahan tersebut. Dia tidak menampik kesalahan itu, namun menginternalisasi dalam diri, dan mencari cara membenahi kesalahan tersebut.

\section{Nilai Pemberdayaan Percaya Diri}

Salah satu nilai pemberdayaan konseli yang diambil dari sari pemikiran Bung Karno dalam buku Sarinah adalah percaya diri. Percaya diri menurut Bung Karno berarti individu atau seseorang harus memiliki kepercayaan pada segenap kemampuan dirinya. Tidak minder dan terlalu bergantung pada orang lain.

Pemikiran Bung Karno ini senada dengan Worrel and Remer (dalam Corey, 2009:349). Menurutnya konselor perlu menfasilitasi konseli untuk trust their own experince and their 
intuition, yakni mempercayai pengalaman dan intuisi mereka. Konseli menurut Worrel dan Remer perlu didorong untuk menggali kemampuan mereka dengan mempercayai pengalaman hidup dan intuisi mereka. Setiap pengalaman dan intuisi berasal dari faktor internal diri. Maka konseli dapat mengambilnya untuk dijadikan kekuatan internal mereka.

Berdikari dalam kepercayaan diri seperti yang digariskan Bung Karno. Ketika konseli mampu percaya diri maka dapat meningkatkan penghargaan atas diri sendiri (self esteem). Konseli mampu memberdayakan diri lewat kemampuan internalnya. Tanpa bergantung berlebihan pada orang lain.

Rogers (dalam Corey, 2009: 170) juga menegaskan konseli yang sehat adalah mereka yang mampu mencapai aktualisasi dalam hal: (1) an openness to experience, (2) a trust in themselves. Artinya konseli mampu untuk terbuka pada pengalaman dirinya, dan memercayai pengalaman diri itu sebagai kepercayaan atas kemampuan mereka. Tidak semata-mata mengandalkan orang lain, namun mempunyai keyakinan percaya pada diri sendiri.

\section{Nilai pemberdayaan memahami orang lain}

Memahami orang lain merupakan pemikiran Bung Karno dalam buku Sarinah yang mengedepankan aspek humanisme interpersonal. Yakni aspek kemanusiaan dalam berinteraksi dengan orang lain. Dengan memahami orang lain, Bung Karno mengajak tiap laki-laki dalam sistem patriarki jahat untuk menyelami perasaan perempuan yang mereka tindas. Dengan begitu, para lelaki tersebut dapat memahami perasaan para perempuan ketika ditindas.

Demikian juga ketika hendak memimpin massa rakyat melawan penindasan. Para pemimpin gerakan feminis perlu mengetahui dan memahami apa kehendak dari massa rakyat yang akan dipimpinnya. Tanpa pemahaman itu, tentu sangat sulit mengajak orang lain untuk berjuang. Pemikiran Bung Karno senada dengan Beck (dalam Yusuf, 2010) yang mengungkapkan bahwa hakikat konseli yang berdaya itu harus memandang atau memperhatikan orang lain sebagai bagian dari dirinya. Dan perhatiannya ini direfleksikan dalam pergaulan dengan warga yang lebih luas.

Beck menggarisbawahi bahwa memandang orang lain sebagai bagian dirinya adalah wujud nilai memahami orang lain. Dia menghargai dan menghormati orang lain layaknya dia menghargai dirinya sendiri. Ketika konseli mampu berdaya dengan tetap memahami orang lain, itu artinya konseli mampu menyesuaikan dengan lingkungan sekitar. Tidak melakukan pemaksaan kehendak atas orang lain berdasarkan ego nya sendiri. Menggali apa yang dirasakan dan dilakukan orang lain untuk kemudian dipahami sesuai konteks lingkungannya masingmasing. 


\section{Nilai Pemberdayaan Bekerjasama}

Bekerjasama menjadi salah satu hal penting yang diingatkan Bung Karno dalam tulisan buku Sarinah. Menurutnya kerjasama perlu dilakukan agar tercipta rasa kebersamaan untuk bahu membahu mencapai tujuan. Baik laki-laki maupun wanita memiliki kewajiban untuk meraih tujuan hidup dengan bekerjasama.

Nilai pemberdayaan kerjasama yang diutarakan Bung Karno ini juga selaras dengan apa yang menjadi tujuan konseling berasas Pancasila. Seperti yang disampaikan Husni Abdillah (2011) Tujuan bimbingan dan konseling harus selaras dan sesuai dengan nilai-nilai yang terkandung dalam setiap sila pancasila. Dengan demikian tujuan bimbingan dan konseling adalah memfasilitasi peserta didik agar mampu; mengembangkan sikap-sikap kooperatif, kolaboratif, toleransi dan altruis (ta'awun bil ma'ruf). Husni menekankan pentingnya sikap kooperatif dan kolaboratif menjadi landasan bagi pemberdayaan konseli. Kooperatif-kolaboratif memiliki makna konseli mampu bekerajsama dengan orang lain untuk mennggapai apa yang diharapkannya. Bertoleransi dan memiliiki keikhlasan dalam bahu membahu bersama orang lain.

Hal ini juga selaras dengan temuan penelitian lain terdahulu. Restu Dwi Apriyanto (2016: 179) mengungkapkan temuan nilai kerjasama perlu dimiliki oleh konseli. Yakni deskripsi perilaku kerjasama dalam hal setiakawan. Artinya pemberdayaan konseli harus lah menfasilitasi konseli untuk bisa menerapkan kerjasama itu dalam bentuk kesetiakawanan dalam arti positif. Nilai pemberdayaan kerjasama konseli membantu konseli memahami dirinya sebagai makhluk sosial. Yakni hidup bersama dengan orang lain dan bahu membahu untuk menjalani kehidupan. Baik di kehidupan sekolah maupun bermasyarakat. Ketika konseli mampu menciptakan iklim kondusif dalam kehidupan sosialnya, maka hidupnya akan penuh warna.

\section{SIMPULAN}

Berdasarkan hasil penelitian yang telah diulas dalam hasil dan pembahasan, dapat disimpulkan bahwa terdapat nilai-nilai pemberdayaan konseli yang bisa digali dari buku Sarinah karya Soekarno, bapak bangsa negara Indonesia ini. Walau telah lama meninggalkan bangsa ini, pemikiran beliau dalam buku Sarinah menegaskan keberpihakannya pada pembelaan bangsa ini tanpa memandang jenis kelamin. Beberapa nilai pemberdayaan konseli yang telah digali, dianalisis, dan dibahas antara lain: 1) nilai pemberdayaan anti penindasan; 2) nilai pemberdayaan adil; 3) nilai pemberdayaan menjunjung kesetaraan; 4) nilai pemberdayaan berpikir terbuka; 5) nilai pemberdayaan koreksi diri; 6) nilai pemberdayaan percaya diri; 7) nilai pemberdayaan memahami orang lain; 8) nilai pemberdayaan kerjasama.

Beberapa nilai tersebut dapat dijadikan sumbangsih nilai pemberdayaan konseli yang dapat difasilitasi konselor. Konselor dapat mengacu pada nilai-nilai tersebut saat menjalankan 
misi pemberdayaan. Nantinya ketika konseli mampu memunculkan nilai pemberdayaan itu pada dirinya, diharapkan kemandirian yang terbentuk benar-benar kuat dan terarah sesuai kepribadian bangsa Indonesia.

\section{SARAN}

Jangan sekali-sekali melupakan sejarah (jasmerah). Kata-kata Bung Karno dalam pidato peringatan hari kemerdekaan Indonesia tahun 1966 dapat menjadi saran ke depan bagi peneliti selanjutnya. Yakni menggali sebanyak-banyaknya nilai-nilai pemberdayaan konseli dari beragam sumber anak bangsa. Karya Bung Karno yang bertebaran banyak baik di jagat cetak maupun dunia maya dapat dijadikan sumber referensi untuk pengembangan ide-ide keilmuan Bimbingan dan Konseling khas Indonesia. Beragam pidato dan tulisannya yang terkenal hingga dunia internasional dapat menjadi inspirasi bagi para peneliti bimbingan konseling selanjutnya. Perlu juga penelitian lebih lanjut bagaimana kontekstualisasi pemikiran Bung Karno tersebut dalam ranah aplikatif. Seperti dalam penerapan konseling, bimbingan kelompok atau treatment lainnya oleh konselor.

\section{DAFTAR PUSTAKA}

Abdillah, H. (2011). Landasan Filosofis Bimbingan dan Konseling, (online) (http: https://abdillahhusni.wordpress.com/category/konseling)

Allende, S. (1973). Last Word To The Nation, (online), (http://www.marxists.org/archive/ allende/1973/september/11.htm)

Alvesson, M. \& Skoldberg, K. (2000). Reflexive Methodology : New Vistas for Qualitative Research. London: SAGE Publications.

Boeree, C.G. (2013). Personality Theories: Melacak Kepribadian Anda Bersama Psikolog Dunia. Jogjakarta : Prismashopie.

Corey, G. (2009). Theory and Practice of Counseling Pshychoteraphy : Eight Edition. Belmont California : Thomson Brooks/Cole

Direktorat Jenderal Guru dan Tenaga Kependidikan Kementerian Pendidikan dan Kebudayaan Republik Indonesia. (2016). Panduan Operasional Penyelenggaraan Bimbingan dan Konseling di SMK Tahun 2016. Jakarta.

Dryden, W. \& Mytton, J. (1999). Four Approaches to Counseling and Psychotherapy. New York : Routledge (Taylor \& Francis Group)

Rahardjo, M. (2008). Hermeneutika Gadamerian Kuasa Bahasa dalam Wacana Politik Gus Dur. Malang : UIN-Malang Press.

Lekachman, R. \& Loon, B.V. (2008). Kapitalisme : Teori dan Sejarah Perkembangan. Jogjakarta : Resist Book.

Mappiare, AT. (2013). Tipe-Tipe Metode Riset Kualiatif untuk Eksplanasi Sosial Budaya dan Bimbingan Konseling. Malang : Elang Mas.

Menteri Pendidikan dan Kebudayaan Republik Indonesia. (2014). Peraturan Menteri Pendidikan dan Kebudayaan Nomor 111 Tahun 2014 Tentang Bimbingan dan Konseling pada Pendidikan Dasar dan Pendidikan Menengah Tahun 2014. Jakarta.

Muwakhidah. (2017). Pendekatan Feminis dalam Konseling, (online) (https://muwakhidahunipa.wordpress.com/bimbingan-dan-konseling)

Prafitralia, A. (2015). Nilai-Nilai Pribadi Ideal Konseli dalam Serat Wulangreh. (Tesis tidak diterbitkan) Universitas Negeri Malang, Malang, Indonesia. 
Roziqi, M. (2017). Nilai-Nilai Pemberdayaan Konseli Berbasis Feminisme Khas Soekarno: Studi Hermeneutika Gadamerian Buku Sarinah. Jurnal Psikoedukasi dan Konseling. 1(1), 33-50

Restu, D.A. (2016). Identifikasi Karakter Ideal Konseli Menurut Teks Kepribadian Founding Fathers Indonesia: Kajian dalam Perspektif Fromm. Jurnal Pendidikan 1(2), 174-182. Retrieved from https://journal.unesa.ac.id/index.php/jp/article/download/235/215

Rueda, M.; Rodrigues, M; Watkins, S.A. (2007). Feminisme Untuk Pemula. Jogjakarta : Resist Book.

Soekarno. (2014). Sarinah : Kewajiban Wanita dalam Perjuangan Republik Indonesia. Jakarta : Yayasan Bung Karno bekerjasama dengan PT Media Pressindo

University of Pennsylvania Authentic Happiness. (n.d.). Retrieved from website : https://www.authentichappiness.sas.upenn.edu/newsletters/authentichappinesscoaching/o pen-mindedness

Wibowo, A.S. (2017). Gaya Filsafat Nietzsche. Jogjakarta : Kanisius

Yusuf, Syamsu dan Nurihsan, Juntika. (2010). Landasan Bimbingan dan Konseling. Bandung:

Remaja Rosdakarya 